Journal of History Culture and Art Research

Revue des Recherches en Histoire Culture et Art

مجلة البحوث التاريخية و الثقافية والفنية
Vol. 2, No. 2, June 2013

Copyright (C) Karabuk University

http://kutaksam.karabuk.edu.tr/index.php

Özel Sayı/Special Issue

(English Studies)

DOI: 10.7596/taksad.v2i2.224

\title{
Teacher Autonomy Perceptions of Iranian and Turkish EFL Teachers
}

\author{
Ebrahim KHEZERLOU*
}

\begin{abstract}
The study aimed at examining Iranian $(\mathrm{N}=218)$ and Turkish $(\mathrm{N}=142)$ high school EFL teachers' opinions about teacher autonomy over (a) the choice of appropriate teaching methods, strategies and techniques and implementation of the established curriculum (b) teacher involvement in decision making processes and (c) teachers' use of personal initiative in solving their work problems. An 11-item questionnaire $(\alpha=.758)$ was used to measure autonomy perceptions of the participants. The results revealed that Turkish teachers' autonomy perceptions were greater than that of Iranian teachers in the three teacher autonomy dimensions. Moreover, it was observed that male and master- holder teachers perceive less autonomy than female and bachelor-holder ones; whereas, no significant relationship were observed for the age and marital status variables with any teacher autonomy dimensions. Lastly, decision making dimension was the strongest predictor of teacher autonomy among both Iranian and Turkish teachers.
\end{abstract}

Keywords: Teacher autonomy, Pedagogical curriculum evaluation, Decision making, Problem solving, EFL teachers, Iran, Turkey

\footnotetext{
* Mevlana University, English Department, Faculty of Education.
} 


\section{Introduction}

Teacher autonomy has generally been defined as the degree to which a teacher has the desire to make curriculum decisions using his/her personal initiative and intellectual engagement. For the first time, Little (1995, p. 176) defined the term as the "teachers' capacity to engage in self-directed teaching". After that, scholars defined teacher autonomy from different aspects. For instance, Aoki (2000, p. 19) suggests that teacher autonomy involves "the capacity, freedom, and/or responsibility to make choices concerning one's own teaching”. Smith (2000, p. 89) also argues that teacher autonomy refers to "the ability to develop appropriate skills, knowledge and attitudes for oneself as a teacher, in cooperation with others." Furthermore, Benson (2000, p. 111) argues that teacher autonomy can be seen as "a right to freedom from control and/or an ability to exercise this right".

Teacher autonomy conceptualizations have considerably been changed over the years and still continue to evolve. As Frase and Sorenson (1992) argue, teacher autonomy is viewed very differently: one teacher may view autonomy as a means to gain substantial freedom from interference or supervision; another may view it as the freedom to develop collegial relationships and accomplish tasks that extend beyond the classroom; and even some others may perceive it as a means for principals to avoid their duties. Although the concept was viewed as a unitary concept in the past, it is recently decomposed into six distinct subcomponents: autonomy over curriculum, pedagogy, assessment, professional development, student discipline, and classroom environment (LaCoe, 2008). These six subcomponents of teacher autonomy provide a solid framework to understand the complex nature of teacher autonomy.

Studies also reveal that teacher autonomy is crucial to educational effectiveness and empowers individuals within the system to adapt teaching to the changing needs of the students and the community. For instance, Pearson and Hall (1993) found that the degree of autonomy perceived by new teachers is an indicator of job satisfaction and a positive reaction to teaching, and teachers who had higher autonomy scores expressed a willingness to enter teaching again if faced with that decision. Moreover, Ingersoll and Alsalam (1997) argued that increasing of teacher autonomy positively correlates with making better decisions about educational issues because top-down decision-making often fails when it lacks the support of those who are responsible for the implementation of them. Finally, perceptions of autonomy have been found to be related to various factors such as tension, frustration, anxiety, and job stress among teachers (Pearson and Hall, 1993; Natale, 1993; Davis and Wilson, 2000; Dinham and Scott, 2000; Webb, 2002; Pearson and Moomaw, 2006; Bustingorry, 2008). 
While the potential role of teacher autonomy in language learning/teaching processes is enormous, it has been argued that Turkey has a centralized educational system (Öztürk, 2011; Uygun, 2008; Akşit, 2007). Yıldırım (2003) analyzes the attitudes and practices of Turkish teachers with regard to their teaching programs and identifies that teachers excessively rely on the curriculum and textbooks in their teaching activities because they are asked to meet fully the predetermined curriculum requirements, meaning that they have little autonomy in determining the content of the teaching activities. He further adds that centralized tendencies are vividly observed in many fields such as curriculum development, choice of instructional materials, teacher employment, in-service training programs, etc. Moreover, Vorkink (2006) claims that "compared with Europe and most of the world, Turkey's public schools have the least autonomy over resources, staff deployment (at the school), textbook selection, allocation of instructional time, and selection of programs offered" (Vorkink, 2006, p. 17).

If this is the case with Turkish educational system, there will be no much difference with the educational system of Iran, where teachers have no flexibility to regulate the content of the programs in accordance with the student needs and classroom circumstances, where teachers' voices most of the time are not asked, where their educational and non-educational issues often remain unsolved, etc. Therefore, the general purpose of the study is to see whether there are similarities or differences between Iranian and Turkish EFL teachers' autonomy perceptions. It is perhaps worth mentioning that our conceptualization in this regard is that of 'agency' concept developed by Paris (1993) who characterizes the relationship of teachers to curriculum. She argues that "teacher agency in curriculum matters involves initiating the creation or critique of curriculum, an awareness of alternatives to established curriculum practices, the autonomy to make informed choices, an investment of self, and on-going interaction with others" (Paris, 1993: 16). To highlight her concept, Paris (1993) contrasts it to commonly held conceptions of 'teachers as consumers of curriculum' and 'technical implementers of ideas and products of experts'. She further adds that teachers who conceptualize themselves as agents involve in curriculum development, implementation and evaluation activities.

It is, however, believed that taking into account EFL teachers' views will shed more light on the importance of teacher autonomy in pedagogical processes. To this end, autonomy perceptions of Iranian and Turkish teachers are studied in the areas of: (a) Pedagogical Curriculum Evaluation referring to the choice of appropriate teaching methods, strategies and techniques and implementation of the established curriculum, (b) Decision Making describing the involvement of teachers in decision making processes, and (c) Problem Solving characterizing teachers' use of personal initiative to solve their work problems. Hence, the paper aims at finding answers to the following research questions: 
1. What is the perceived level of teacher autonomy for Iranian and Turkish secondary EFL teachers in the three dimensions of (a) pedagogical curriculum evaluation, (b) decision making, and (c) problem solving?

2. Are there significant differences between EFL teachers' autonomy perceptions in areas of (a) pedagogical curriculum evaluation, (b) decision making, and (c) problem solving and their socio-demographic variables of (a) nationality, (b) gender, (c) academic level, (d) age, and (e) marital status?

3. What are the strongest predictors of teacher autonomy across Iranian and Turkish EFL teachers?

\section{Methodology}

The participants were 360 high school teachers teaching English as foreign language in state schools of Iran and Turkey during 2011-2012 academic year. The data for the study were collected from North West provinces of Iran (East Azerbaijan, West Azerbaijan, Erdebil, Zenjan, and Kazvin) and four city regions of Ankara (Mamak, Çankaya, Altındağ, and Balgat) in Turkey. An 11-item questionnaire was developed based on the literature study to measure autonomy perceptions of EFL teachers in the areas of Pedagogical Curriculum Evaluation (4 items), Decision Making (4 items), and Problem Solving (3 items), each of which uses a six-point Likert scale ranging from 'disagree very much' (1) to 'agree very much' (6). The average internal consistency reliability coefficient of the 11 -item questionnaire was 0.758 , which indicates an acceptable reliability index for the measure. The collected data were entered into the SPSS version 17.0 for Windows for analysis. Descriptive and inferential statistics such as per cent, mean, t-test, ANOVA, and standard multiple regression were used for determining and explaining relationships between the variables.

\section{Results}

The results were offered based on the order of the research questions.

\subsection{Autonomy perceptions of Iranian and Turkish teachers}

To obtain a model for presenting the descriptive results of autonomy perceptions of Iranian and Turkish teachers, first, the perfect scores of teacher autonomy variable and its dimensions were exclusively summed, then, their perfect scores were divided into three to get the appropriate cut-off points for each of them. The perfect scores for overall teacher autonomy and its dimensions were as: Overall Teacher Autonomy (1-66), Pedagogical Curriculum Evaluation (1-24), Decision Making (1-24), and Problem Solving (1-18). Autonomy perceptions were 
considered as 'low' if they were within the low score category of each variable's total range, 'moderate' if they were within the middle score category of the total range, and 'high' if they were within the high score category of the total range. The cut-off points for the variables were as: Overall Teacher Autonomy (Low $=1-22$, Moderate $=23-44$, High $=45-66$ ), Pedagogical Curriculum Evaluation and Decision Making dimensions (Low $=1-8$, Moderate $=9-16$, High $=$ 17-24), and Problem Solving dimension $($ Low $=1-6$, Moderate= 7-12, High = 13-18) $($ See Table $1)$.

Based on this self-developed cut-off points, the results of Iranian and Turkish teachers' autonomy perceptions in the variables were as: for Iranian teachers $>$ Pedagogical Curriculum Evaluation $(\mathrm{Low}=22.0 \%$, Moderate $=67.9 \%$, and High $=10.1 \%)$, Decision Making $($ Low $=$ 17.4\%, Moderate $=68.8 \%$, and High $=13.8 \%)$, Problem Solving $($ Low $=41.3 \%$, Moderate $=$ 42.7\%, and High $=16.1 \%)$, and Overall Teacher Autonomy $($ Low $=10.6 \%$, Moderate $=80.7 \%$, and High $=8.7 \%$ ), and for Turkish ones $>$ Pedagogical Curriculum Evaluation (Low $=6.3 \%$, Moderate $=75.4 \%$ and High $=18.3 \%)$, Decision Making $($ Low $=9.2 \%$, Moderate $=62.0 \%$ and High $=28.9 \%)$, Problem Solving $($ Low $=31.7 \%$, Moderate $=45.1 \%$ and High= 23.2\% , and Overall Teacher Autonomy (Low $=2.1 \%$, Moderate $=76.8 \%$ and High $=21.1 \%)($ See Table 1$)$.

Table 1. Frequency and Percentage of Iranian and Turkish Teachers' Autonomy Perceptions

\begin{tabular}{|c|c|c|c|c|c|c|c|c|c|c|c|c|}
\hline \multirow{3}{*}{ Variables } & \multicolumn{4}{|c|}{ Low } & \multicolumn{4}{|c|}{ Moderate } & \multicolumn{4}{|c|}{ High } \\
\hline & \multicolumn{2}{|c|}{ Ir. } & \multicolumn{2}{|c|}{ Tr. } & \multicolumn{2}{|c|}{ Ir. } & \multicolumn{2}{|c|}{ Tr. } & \multicolumn{2}{|c|}{ Ir. } & \multicolumn{2}{|c|}{ Tr. } \\
\hline & $\mathrm{F}$ & $\%$ & $\mathrm{~F}$ & $\%$ & $\mathrm{~F}$ & $\%$ & $\mathrm{~F}$ & $\%$ & $\mathrm{~F}$ & $\%$ & $\mathrm{~F}$ & $\%$ \\
\hline Curriculum Evaluation & 48 & 22.0 & 9 & 6.3 & 148 & 67.9 & 107 & 75.4 & 22 & 10.1 & 26 & 18.3 \\
\hline Decision Making & 38 & 17.4 & 13 & 9.2 & 150 & 68.8 & 88 & 62.0 & 30 & 13.8 & 41 & 28.9 \\
\hline Problem Solving & 90 & 41.3 & 45 & 31.7 & 93 & 42.7 & 64 & 45.1 & 35 & 16.1 & 33 & 23.2 \\
\hline Overall Autonomy & 23 & 10.6 & 3 & 2.1 & 176 & 80.7 & 109 & 76.8 & 19 & 8.7 & 30 & 21.1 \\
\hline $\begin{array}{l}\text { * The cut-off points bel } \\
\text { Pedagogical Curriculum } \\
\text { Problem Solving dimen } \\
\text { Overall Autonomy (Lou }\end{array}$ & $\begin{array}{l}\text { the } \\
\text { uati } \\
\text { Low } \\
22,\end{array}$ & $\begin{array}{l}\text { searc } \\
\text { and I } \\
1-6, \\
\text { derat }\end{array}$ & ode & $\begin{array}{l}\text { Mak } \\
=7 \\
\mathrm{Hi}\end{array}$ & $\begin{array}{l}\text { limen } \\
\text { ligh } \\
45-6\end{array}$ & $\begin{array}{l}\text { ons (I } \\
13-18\end{array}$ & & $8, \mathrm{Mc}$ & & 6, Hig & $=1$ & \\
\hline
\end{tabular}

\subsection{Socio-demographic variables and teacher autonomy}

The analyses of this section were offered based on the categorical variables included in the study, where the teacher autonomy variable and its dimensions (i.e., pedagogical curriculum evaluation, decision making, and problem solving) were our dependent variables and nationality, gender, academic level, age, and marital status were independent ones. 


\subsubsection{Nationality and teacher autonomy}

The results of T-test analyses for nationality variable showed that there were statistically significant differences between Iranian $(\mathrm{N}=218)$ and Turkish $(\mathrm{N}=142)$ teachers' autonomy perceptions in the three dimensions of Pedagogical Curriculum Evaluation $(t=-5.337 ; P=.000$, $P<.05)$, Decision Making $(t=-4.901 ; P=.000, P<.05)$, and Problem Solving $(t=-3.114 ; P=$ $.002, P<.05)$. When the three dimensions were summed, significant difference was expectedly observed between the groups' Overall Autonomy perceptions $(t=-5.608 ; P=.000, P<.05)$ (See Table 2).

Moreover, the Effect Size statistics indicated a slight significant difference between Iranian and Turkish groups in Problem Solving $\left(\eta^{2}=0.026 ; \eta^{2}<0.059\right)$ dimension, but moderate differences in Pedagogical Curriculum Evaluation $\left(\eta^{2}=.074 ; \eta^{2}>.06<.139\right)$, Decision Making $\left(\eta^{2}=.063 ; \eta^{2}>.06<.139\right)$, and Overall Autonomy $\left(\eta^{2}=.081 ; \eta^{2}>.06<.139\right)$. Cohen's (1988) Effect Size indexes for the ratio of variance between the dependent and independent variables, computed through the $" \eta^{2}=\mathrm{t}^{2} / \mathrm{t}^{2}+\left(\mathrm{N}_{1}+\mathrm{N}_{2}-2\right)$ ' formula for $\mathrm{t}$-tests, are as: small=0.01to 0.059 , medium $=0.06$ to 0.139 and large $=0.14$ to 1 (See Table 2$)$.

Table 2. Nationality and Teacher Autonomy

\begin{tabular}{|c|c|c|c|c|c|c|c|}
\hline \multirow[b]{2}{*}{ Variables } & \multicolumn{3}{|c|}{ Group statistics } & \multicolumn{4}{|c|}{ t-test } \\
\hline & Nationality & $\mathrm{N}$ & Mean & $\mathrm{t}$ & $\mathrm{df}$ & Sig. & $\eta^{2}$ \\
\hline \multirow{2}{*}{ Curriculum Evaluation } & Iranian & 218 & 11.81 & \multirow{2}{*}{-5.337} & \multirow{2}{*}{325.58} & \multirow{2}{*}{.000} & \multirow{2}{*}{.074} \\
\hline & Turkish & 142 & 13.76 & & & & \\
\hline \multirow{2}{*}{ Decision Making } & Iranian & 218 & 12.26 & \multirow{2}{*}{-4.901} & \multirow{2}{*}{358} & \multirow{2}{*}{.000} & \multirow{2}{*}{.063} \\
\hline & Turkish & 142 & 14.30 & & & & \\
\hline \multirow{2}{*}{ Problem Solving } & Iranian & 218 & 9.08 & \multirow[t]{2}{*}{-3.114} & \multirow[t]{2}{*}{358} & \multirow[t]{2}{*}{.002} & \multirow[t]{2}{*}{.026} \\
\hline & Turkish & 142 & 10.23 & & & & \\
\hline \multirow{2}{*}{ Overall Autonomy } & Iranian & 218 & 33.15 & \multirow[t]{2}{*}{-5.608} & \multirow[t]{2}{*}{358} & \multirow[t]{2}{*}{.000} & \multirow[t]{2}{*}{.081} \\
\hline & Turkish & 142 & 38.29 & & & & \\
\hline
\end{tabular}

\subsubsection{Gender and teacher autonomy}

There was statistically significant difference, as determined by T-test, between Male $(\mathrm{N}=$ $170)$ and Female $(\mathrm{N}=190)$ EFL teachers' autonomy perceptions in the dimension of Decision Making $(t=-3.153 ; P=.002, P<.05)$ because the observed P-values was less than 0.05 . However, no significant difference was observed between the groups in the dimensions of Pedagogical Curriculum Evaluation $(t=-1.651 ; P=.100, P>.05)$ and Problem Solving $(t=-$ 
$1.040 ; P=.299, P>.05)$. Significant difference was also observed between the groups' Overall Autonomy perceptions $(t=-2.494 ; P=.013, P<.05)$ (See Table 3$)$.

Further, the Effect Size statistics revealed slight differences for the male and female groups in Decision Making $\left(\eta^{2}=.027 ; \eta^{2}<0.059\right)$ dimension and Overall Autonomy $\left(\eta^{2}=.017 ; \eta^{2}\right.$ $<0.059$ ) (See Table 3).

Table 3. Gender and Teacher Autonomy

\begin{tabular}{|c|c|c|c|c|c|c|c|}
\hline \multirow[b]{2}{*}{ Variables } & \multicolumn{3}{|c|}{ Group statistics } & \multicolumn{4}{|c|}{ t-test } \\
\hline & Gender & $\bar{N}$ & Mean & $\mathrm{t}$ & $\overline{d f}$ & Sig. & $\overline{\eta^{2}}$ \\
\hline \multirow[t]{2}{*}{ Curriculum Evaluation } & Male & 170 & 12.25 & -1.651 & 358 & .100 & - \\
\hline & Female & 190 & 12.87 & & & & \\
\hline \multirow[t]{2}{*}{ Decision Making } & Male & 170 & 12.37 & -3.153 & 358 & .002 & .027 \\
\hline & Female & 190 & 13.68 & & & & \\
\hline \multirow[t]{2}{*}{ Problem Solving } & Male & 170 & 9.33 & -1.040 & 358 & .299 & - \\
\hline & Female & 190 & 9.72 & & & & \\
\hline \multirow[t]{2}{*}{ Overall Autonomy } & Male & 170 & 33.95 & -2.494 & 358 & .013 & .017 \\
\hline & Female & 190 & 36.27 & & & & \\
\hline
\end{tabular}

\subsubsection{Academic level and teacher autonomy}

There was statistically significant difference between the Bachelor-holder $(\mathrm{N}=234)$ and Master-holder ( $\mathrm{N}=126)$ teachers' autonomy perceptions in the dimension of Decision Making ( $t$ $=2.254 ; P=.025, P<.05)$, while no significant difference was observed between the groups in the dimensions of Pedagogical Curriculum Evaluation ( $t=1.067 ; P=.287, P>.05)$ and Problem Solving ( $t=1.938 ; P=.053, P>.05)$. Significant difference was also observed between the groups' Overall Autonomy perceptions $(t=2.208 ; P=.028, P<.05)$ (See Table 4$)$.

Additionally, the Effect Size statistics showed slight differences for the groups in Decision Making $\left(\eta^{2}=.014 ; \eta^{2}<0.059\right)$ and Overall Autonomy $\left(\eta^{2}=.013 ; \eta^{2}<0.059\right)$ (See Table 4).

Table 4. Academic Level and Teacher Autonomy

\begin{tabular}{|c|c|c|c|c|c|c|c|}
\hline \multirow{2}{*}{ Variables } & \multicolumn{3}{|c|}{ Group statistics } & \multicolumn{4}{|c|}{ t-test } \\
\hline & Academic & $\mathrm{N}$ & Mean & $\mathrm{t}$ & $\mathrm{df}$ & Sig. & $\eta^{2}$ \\
\hline Curriculum Evaluation & $\begin{array}{c}\text { Bachelor } \\
\text { Master }\end{array}$ & $\begin{array}{l}234 \\
126\end{array}$ & $\begin{array}{l}12.73 \\
12.30\end{array}$ & 1.067 & 358 & .287 & - \\
\hline Decision Making & $\begin{array}{l}\text { Bachelor } \\
\text { Master }\end{array}$ & $\begin{array}{l}234 \\
126\end{array}$ & $\begin{array}{l}13.41 \\
12.42\end{array}$ & 2.254 & 358 & .025 & .014 \\
\hline Problem Solving & $\begin{array}{c}\text { Bachelor } \\
\text { Master }\end{array}$ & $\begin{array}{l}234 \\
126\end{array}$ & $\begin{array}{l}9.79 \\
9.06\end{array}$ & 1.938 & 358 & .053 & - \\
\hline Overall Autonomy & $\begin{array}{c}\text { Bachelor } \\
\text { Master }\end{array}$ & $\begin{array}{l}234 \\
126\end{array}$ & $\begin{array}{l}35.93 \\
33.78\end{array}$ & 2.208 & 358 & .028 & .013 \\
\hline
\end{tabular}




\subsubsection{Age and teacher autonomy}

The results of One-way ANOVA analyses showed that there were statistically no significant differences between the Age variable and the three dimensions of Pedagogical Curriculum Evaluation $(F(5,354)=.904, P=.478, P>.05)$, Decision Making $(F(5,354)=$ $1.298, P=.264, P>.05)$, and Problem Solving $(F(5,354)=.517, P=.764, P>.05)$. Expectedly, no significant difference was also observed for the age groups' Overall Autonomy $(F(5,354)=$ $1.003, P=.416, P>.05)($ See Table 5).

Table 5. Age and Teacher Autonomy

\begin{tabular}{|c|c|c|c|c|c|c|c|}
\hline \multirow[b]{2}{*}{ Variables } & \multicolumn{3}{|c|}{ Group statistics } & \multicolumn{4}{|c|}{ ANOVA } \\
\hline & Age & $\overline{\mathrm{N}}$ & Mean & $\bar{F}$ & $\overline{\mathrm{df}}$ & Sig. & $\overline{\eta^{2}}$ \\
\hline \multirow{6}{*}{ Curriculum Evaluation } & $25 \&$ below & 13 & 12.23 & \multirow{6}{*}{.904} & \multirow{6}{*}{$5 ; 354$} & \multirow{6}{*}{.478} & \multirow{6}{*}{-} \\
\hline & 26 to 30 & 43 & 12.35 & & & & \\
\hline & 31 to 35 & 63 & 12.41 & & & & \\
\hline & 36 to 40 & 114 & 12.24 & & & & \\
\hline & 41 to 45 & 101 & 12.95 & & & & \\
\hline & $46 \&$ above & 26 & 13.58 & & & & \\
\hline \multirow{6}{*}{ Decision Making } & $25 \&$ below & 13 & 12.92 & \multirow{6}{*}{1.298} & \multirow{6}{*}{$5 ; 354$} & \multirow{6}{*}{.264} & \multirow{6}{*}{-} \\
\hline & 26 to 30 & 43 & 14.23 & & & & \\
\hline & 31 to 35 & 63 & 12.91 & & & & \\
\hline & 36 to 40 & 114 & 12.58 & & & & \\
\hline & 41 to 45 & 101 & 13.16 & & & & \\
\hline & $46 \&$ above & 26 & 13.58 & & & & \\
\hline \multirow{6}{*}{ Problem Solving } & $25 \&$ below & 13 & 9.54 & \multirow{6}{*}{.517} & \multirow{6}{*}{$5 ; 354$} & \multirow{6}{*}{.764} & \multirow{6}{*}{-} \\
\hline & 26 to 30 & 43 & 9.72 & & & & \\
\hline & 31 to 35 & 63 & 9.24 & & & & \\
\hline & 36 to 40 & 114 & 9.34 & & & & \\
\hline & 41 to 45 & 101 & 9.64 & & & & \\
\hline & $46 \&$ above & 26 & 10.38 & & & & \\
\hline \multirow{6}{*}{ Overall Autonomy } & $25 \&$ below & 13 & 34.69 & \multirow{6}{*}{1.003} & \multirow{6}{*}{$5 ; 354$} & \multirow{6}{*}{.416} & \multirow{6}{*}{-} \\
\hline & 26 to 30 & 43 & 36.30 & & & & \\
\hline & 31 to 35 & 63 & 34.56 & & & & \\
\hline & 36 to 40 & 114 & 34.10 & & & & \\
\hline & 41 to 45 & 101 & 35.75 & & & & \\
\hline & $46 \&$ above & 26 & 37.54 & & & & \\
\hline
\end{tabular}

\subsubsection{Marital status and teacher autonomy}

The results of One-way ANOVA analyses showed statistically no significant differences between the Marital status variable and the three dimensions of Pedagogical Curriculum Evaluation $(F(5,354)=.904, P=.478, P>.05)$, Decision Making $(F(5,354)=1.298, P=.264$, $P>.05)$, and Problem Solving $(F(5,354)=.517, P=.764, P>.05)$. Expectedly, no significant difference was also observed for the age groups' Overall Autonomy $(F(5,354)=1.003, P=.416$, $P>$.05) (See Table 6). 
Table 6. Marital Status and Teacher Autonomy

\begin{tabular}{|c|c|c|c|c|c|c|c|}
\hline \multirow[b]{2}{*}{ Variables } & \multicolumn{3}{|c|}{ Group statistics } & \multicolumn{4}{|c|}{ ANOVA } \\
\hline & Marital & $\mathrm{N}$ & Mean & $\bar{F}$ & $\overline{d f}$ & Sig. & $\eta^{2}$ \\
\hline \multirow{3}{*}{ Curriculum Evaluation } & Single & 59 & 12.83 & \multirow{3}{*}{.497} & \multirow{3}{*}{$2 ; 357$} & \multirow{3}{*}{.609} & \multirow{3}{*}{-} \\
\hline & Married & 287 & 12.49 & & & & \\
\hline & Divorced & 14 & 13.29 & & & & \\
\hline \multirow{3}{*}{ Decision Making } & Single & 59 & 13.20 & \multirow{3}{*}{.059} & \multirow{3}{*}{$2 ; 357$} & \multirow{3}{*}{.943} & \multirow{3}{*}{ - } \\
\hline & Married & 287 & 13.04 & & & & \\
\hline & Divorced & 14 & 12.86 & & & & \\
\hline \multirow{3}{*}{ Problem Solving } & Single & 59 & 9.73 & \multirow{3}{*}{.721} & \multirow{3}{*}{$2 ; 357$} & \multirow{3}{*}{.487} & \multirow{3}{*}{-} \\
\hline & Married & 287 & 9.45 & & & & \\
\hline & Divorced & 14 & 10.50 & & & & \\
\hline \multirow{3}{*}{ Overall Autonomy } & Single & 59 & 35.76 & \multirow{3}{*}{.389} & \multirow{3}{*}{$2 ; 357$} & \multirow{3}{*}{.678} & \multirow{3}{*}{-} \\
\hline & Married & 287 & 34.98 & & & & \\
\hline & Divorced & 14 & 36.64 & & & & \\
\hline
\end{tabular}

\subsection{Predictors of teacher autonomy}

The results of multiple stepwise-method regression analyses for determining the prediction variance of the three teacher autonomy dimensions showed that Decision Making $(t=$ 1.617; Beta $=.455)$ dimension's Beta value was greater than that of the Pedagogical Curriculum Evaluation $(t=1.467$; Beta $=.434)$ and Problem Solving $(t=1.310$; Beta $=.416)$ dimensions among Iranian teachers, respectively. They also revealed that Decision Making $(t=1.563$; Beta $=$ .452) dimension's Beta value was greater than that of the Problem Solving $(t=1.324$; Beta $=$ .383) and Pedagogical Curriculum Evaluation $(t=1.302$; Beta $=.371)$ dimensions among Turkish teachers, respectively (See Table 7).

Table 7. Predictors of Teacher Autonomy

\begin{tabular}{|c|c|c|c|c|c|c|}
\hline \multirow[t]{2}{*}{ Dimensions } & \multicolumn{3}{|c|}{ Iranian Group } & \multicolumn{3}{|c|}{ Turkish Group } \\
\hline & Beta & $\mathrm{t}$ & Sig. & Beta & $\mathrm{t}$ & Sig. \\
\hline Curriculum Evaluation & .434 & 1.467 & .000 & .371 & 1.302 & .000 \\
\hline Decision Making & .455 & 1.617 & .000 & .452 & 1.563 & .000 \\
\hline Problem Solving & .416 & 1.310 & .000 & .383 & 1.324 & .000 \\
\hline
\end{tabular}

\section{Discussion}

The above findings are discussed here to find answers to the research questions which were the objectives of this study. The percentage scores revealed that Turkish teachers perceive more teacher autonomy than Iranian teachers in the three dimensions of pedagogical curriculum evaluation, decision making, and problem solving because the scores of Turkish teachers were greater than that of Iranian ones (See Table 1). Likewise, the t-test results for potential difference 
between Iranian and Turkish teachers' autonomy perceptions revealed high mean scores for Turkish teachers in the three dimensions of pedagogical curriculum evaluation (Iranian $>$ mean= 11.81; Turkish $>$ mean $=13.76)$, decision making $($ Iranian $>$ mean $=12.26$; Turkish $>$ mean $=$ 14.30), and problem solving (Iranian $>$ mean=9.08; Turkish $>$ mean $=10.23$ ) (See Table 2). This implies that Turkish teachers feel more autonomy than Iranian ones in (a) choosing appropriate teaching methods, strategies and techniques to meet student needs, (b) benefiting a flexible curriculum, (c) being involved in decision making processes, and (d) using personal initiative to solve their work problems. Therefore, it can be argued that Turkey has a less centralized EFL curriculum than Iran though it has been argued that Turkish educational system is more centralized and restricted (Yıldırım, 2003, Vorkink, 2006, Akşit, 2007; Uygun, 2008; Öztürk, 2011). However, it is speculated that either Iranian teachers are not aware of their autonomy in these areas or that they really are not given enough opportunity to apply appropriate teaching methodology to meet student needs, to get rid of the excessive reliance on the curriculum in their teaching activities, to participate in various forms of school decision-making activities, and to use personal initiative to solve their work problems. Accordingly, we have answered to our first research question.

Moreover, the findings were statistically significant between male and female groups only in the subscale of decision making dimension, but not in the pedagogical curriculum evaluation and problem solving dimensions, where the mean score of females (mean $=13.68$ ) was greater than that of males (mean $=12.37)($ See Table 3$)$. This means that females think they are involved in decision making processes more than males. This may be attributed to the nature of women who take matters superficially and cannot bring all possible causes of a problem together to analyze and understand it deeply. Furthermore, the findings for the academic levels of Bachelor's Degree and Master's Degree were statistically significant in decision making dimension, but not in the pedagogical curriculum evaluation and problem solving dimensions (See Table 4). The mean score of B.A. degree holders (mean=13.41) in the significant dimension was greater than that of the M.A. degree holders (mean=12.42), that is, the M.A. degree holders perceive they are not involved enough in decision making processes in comparison with the B.A. holders. This can be attributed to their knowledge and experience in understanding the problems better than B.A. degree holders because the higher the academic level, the less perception of autonomy. With regard to age and marital status socio-demographic variables, the findings demonstrated that there were statistically no significant differences between these variables and any dimension of teacher autonomy variable (See Tables 5 and 6). Thus, the second research question was answered.

Finally, the regression findings revealed that the Beta value of Decision Making dimension (Iranian $>\mathrm{t}=1.617$, Beta $=.455$; Turkish $>\mathrm{t}=1.563$, Beta $=.452$ ) was greater than 
that of the other dimensions among both Iranian and Turkish teachers, that is, Teacher Autonomy was strongly predicted by the Decision Making dimension among these groups. That is also to say, the involvement of teachers in decision making processes is the main factor to increase the sense of autonomy among teachers from Iranian and Turkish teachers' perspectives. The second strong factor from Iranian teachers' perspectives is Pedagogical Curriculum Evaluation $(\mathrm{t}=$ 1.467 , Beta $=.434)$, whereas from Turkish teachers' is Problem Solving $(t=1.324$, Beta $=.383)$ (See Table 7). That is, Iranian teachers think that teachers should follow a less restricted curriculum to increase sense of autonomy, while Turkish teachers think they should be allowed to use their personal initiative in solving work problems. In short, to develop teacher autonomy perceptions among our EFL teachers, they should principally be involved in decision making processes through leaving place for their voices, explaining adequately the made decisions, taking steps to deal decisions with them in a truthful manner, explaining decisions in a timely manner, providing opportunities to challenge the made decisions, etc. Accordingly, we have answered to our last research question.

\section{Conclusion and implication}

The aim of this study was to find Iranian and Turkish EFL teachers' opinions about (a) choice of appropriate teaching methods, strategies and techniques to meet student needs, (b) teacher involvement in decision making processes and (c) using personal initiative in solving problems to see whether the established curriculum leaves any place for teacher autonomy. The results revealed that Turkish teachers' autonomy perceptions were greater than that of Iranian teachers in the three teacher autonomy dimensions. Thus, it was concluded that Turkey has a less centralized EFL curriculum than Iran. Moreover, it was observed that male teachers perceive they are not involved enough in decision making processes and the M.A. holders perceive less autonomy than the B.A. holders. And, age and marital status variables were not significant in any teacher autonomy dimensions. At last, decision making dimension was the strongest predictor of teacher autonomy among both Iranian and Turkish teachers. However, these findings may especially be beneficial to policy makers and curriculum designers in developing a curriculum meeting the needs of teachers and students. 


\section{References}

Akşit, N. (2007). Educational reform in Turkey. International Journal of Educational Development, 27, 129- 137.

Aoki, N. (2000). Aspects of teacher autonomy: Capacity, freedom and responsibility. Paper presented at 2000 Hong Kong University of Science and Technology Language Centre Conference.

Benson, P. (2000). 'Autonomy as a learners' and teachers' right'. In B. Sinclair, I. McGrath and T. Lamb (eds.) Learner autonomy, teacher autonomy: Future directions. London: Longman.

Bustingorry, S. O. (2008). Towards teachers' professional autonomy through action research. Educational Action Research, 16(3), 407-420.

Cohen, J. W. (1988). Statistical power analysis for the behavioral sciences (2nd Ed.) Hillsdale, NJ: Lawrence Erlbaum Associates.

Davis, J. and Wilson, S. M. (2000). Principals' Efforts to Empower Teachers: Effects on Teacher Motivation and Job Satisfaction and Stress. The Clearing House [Online], 73(6), 349-353. Retrieved on April 12, 2012 from the World Wide Web: http://libproxy.uwstout.edu:cgi/bin/webcl.

Dinham, S. and Scott, C. (2000). Moving into the third, outer domain of teacher satisfaction. Journal of Educational Administration, Vol. 38, 379-396.

Frase, L. E. and Sorenson, L. (1992). Teacher motivation and satisfaction: Impact on participatory management. NASSP Bulletin (January 1992): 37-43.

Ingersoll, R. M. and Alsalam, N. (1997). Teacher professionalization and teacher commitment: A multilevel analysis (SASS 97-069). Washington, DC: U.S. Department of Education, National Center for Educational Research and Improvement.

LaCoe, C., S. (2008). Teacher Autonomy: a multifaceted approach for the new millennium. New York:Cambria Press.

Little, D (1995). Learning as dialogue: The dependence of learner autonomy on teacher autonomy. System 23/2, 175-182.

Natale, J. A. (1993). Why teachers leave. The Executive Educator, 15, 14-18.

Öztürk, H. İ. (2011). Curriculum Reform and Teacher Autonomy in Turkey: the Case of the History Teaching. International Journal of Instruction, Vol. 4, No: 2, 113- 128.

Paris, C. (1993). Teacher agency and curriculum making in classrooms. New York: Teachers College Press. 
Pearson, L. C. and Hall, B. W. (1993). Initial construct validation of the teaching autonomy scale. Journal of Educational Research, 86(3), 172-177.

Pearson, L. C. and Moomaw, W. (2006). Continuing validation of the teaching autonomy scale. The Journal of Educational Research, 100(1), 44-51.

Smith, R. C. (2000). 'Starting with ourselves: Teacher-learner autonomy in language learning'. In B. Sinclair, I. McGrath and T. Lamb (eds.) Learner autonomy, teacher autonomy: Future directions. London: Longman.

Uygun, S. (2008). The impact of John Dewey on the teacher education system in Turkey. AsiaPacific Journal of Teacher Education, 36(4), 291-307.

Vorkink, A. (2006). Education reform and employment: Remarks delivered at Istanbul Chamber of Commerce. Retrieved September 11, 02, 2011, from http://go.worldbank.org/TPKEOECXI0.

Webb, P. T. (2002). Teacher power: The exercise of professional autonomy in an era of strict accountability. Teacher Development, 6(1), 47-62.

Y1ldirım, A. (2003). Instructional planning in a centralized school system: Lessons of a study among primary school teachers in Turkey. International Review of Education, 49(5), 525-543. 